\title{
Dengue and chikungunya infection in neurologic disorders from endemic areas in Brazil
}

Cíntia da Silva Mello, MSc, Mauro Jorge Cabral-Castro, PhD, Luiz Claudio Silva de Faria, BSc, José Mauro Peralta, MD, PhD, and Marzia Puccioni-Sohler, MD, PhD

Neurology: Clinical Practice Month 2019 vol. 00 no. 00 1-6 doi:10.1212/CPJ.0000000000000776
Correspondence

Dr. Puccioni-Sohler

m_puccioni@yahoo.com.br

\section{Abstract}

\section{Objective}

To detect the frequency of dengue virus (DENV), Chikungunya virus (CHIKV), and Zika virus (ZIKV) in adult patients with suspected viral infection of the CNS or postinfectious syndromes living in the state of Rio de Janeiro, Brazil.

\section{Methods}

DENV, CHIKV, and ZIKV RNA by reverse transcription PCR (RT-PCR) and specific IgM antibodies were investigated in 47 CSF and serum samples of 36 adult patients suspected with viral infection or postinfectious neurologic diseases. In addition, intrathecal synthesis of anti-DENV and anti-CHIKV IgG antibodies was also evaluated using a specific antibody index.

\section{Results}

Of the total group, neuroinvasive arbovirus was confirmed in 31\%

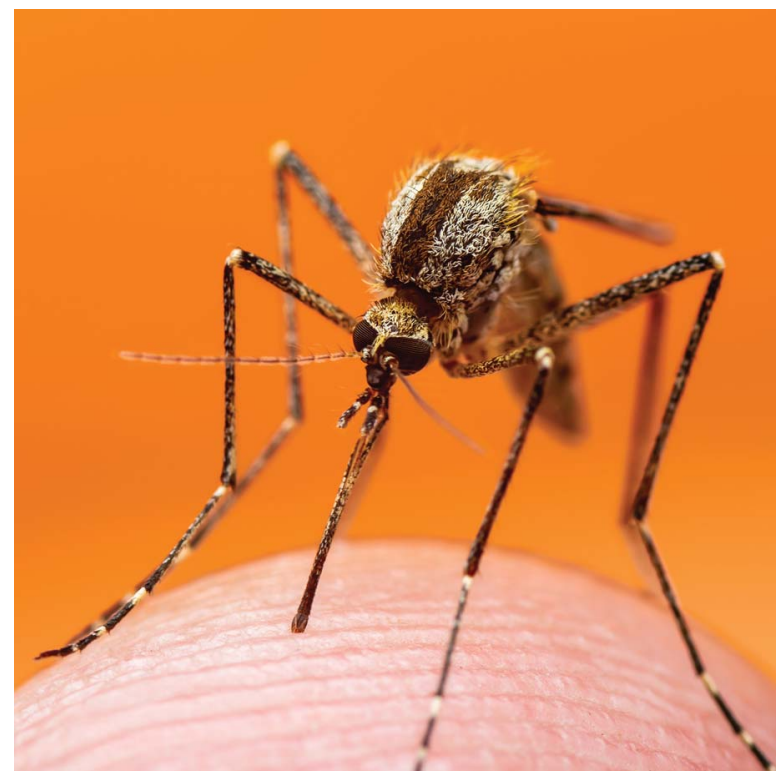
(11/36) of the cases: 6 (55\%) by RT-PCR in CSF and/or serum, 1 (9\%) by RT-PCR in CSF and/or serum and specific IgM in CSF, and 4 (36\%) by specific IgM in CSF. Five cases had DENV infection, and 6 patients were positive for CHIKV. No sample amplified for ZIKV. In addition, 3 of 7 (42\%) tested cases had intrathecal synthesis of DENV or CHIKV antibodies. The neurologic complications included encephalitis (7), Guillain-Barré syndrome (2), optic neuritis (1), neuromyelitis optica spectrum disorder (1), polyneuropathy, (1) and myelitis (1).

\section{Conclusion}

DENV and CHIKV are a frequent cause of emerging and reemerging infections. It increases the number of cases with neurologic complications worldwide. We demonstrated that the combined use of molecular and immunologic tests in CSF/serum might support more widely the diagnosis of neurologic disorders caused by arbovirus in endemic areas. The detection of intrathecal synthesis of specific IgG antibodies may be promising for the retrospective diagnosis of neuroinvasive disorders caused by arbovirus.

Dengue virus (DENV), Zika virus (ZIKV), and Chikungunya virus (CHIKV) are arthropodborne viruses (arboviruses) transmitted by infected Aedes species mosquitoes. These arboviruses are present in the subtropical and tropical regions of the world. There are around 4 billion people living in endemic areas including more than 120 countries. Although most cases are asymptomatic, the development of hemorrhagic conditions and hypovolemic shock

Universidade Federal do Rio de Janeiro (UFRJ) (CDSM, MJC-C, LCSDF, JMP, MP-S), Rio de Janeiro, Brazil; and Universidade Federal do Estado do Rio de Janeiro (UNIRIO) (CDSM, MP-S), Rio de Janeiro, Brazil.

Funding information and disclosures are provided at the end of the article. Full disclosure form information provided by the authors is available with the full text of this article at Neurology.org/cp. 
We evaluated the frequency of arbovirus infection in adult patients with suspected viral infection of the CNS or post-infectious syndromes living in the State of Rio de Janeiro, Brazil.

because of these febrile diseases may occur. ${ }^{1}$ In addition, there has been an increase in the occurrence of severe neurologic manifestations associated with these viruses, such as encephalitis, meningitis, Guillain-Barré syndrome (GBS), and congenital disorders. ${ }^{1-5}$ It represents a serious public health problem because of the high morbidity, mortality, and underestimated diagnosis and is also a challenge for neurology.

Neurologic symptoms are not specific for these arboviruses, making diagnosis difficult. ${ }^{1,5,6}$ Laboratorial diagnosis with the detection of ZIKV, CHIKV, and DENV nucleic acid by reverse transcription PCR (RT-PCR) in any samples confirms the infection. The specific IgM (ELISA) in CSF is also a confirmatory test because other arboviruses endemic in the area had been excluded. ${ }^{1,7,8}$ However, in cases of negative results for ZIKV and DENV by RT-PCR with positive IgM for both viruses, confirmatory neutralizing antibodies and/or paired acute and convalescent serum samples are often needed to confirm recent arboviral infection because of the possibility of cross-reaction among viruses within the same viral genus.

Intrathecal synthesis of specific antibodies has been used as an important tool for the diagnosis of inflammatory disorders of the CNS. ${ }^{5,6,9}$

We evaluated the frequency of arbovirus infection in adult patients with suspected viral infection of the CNS or postinfectious syndromes living in the state of Rio de Janeiro, Brazil, based on the combined use of molecular and immunologic specific tests in CSF/serum and intrathecal synthesis of specific IgG antibodies. ${ }^{10,11}$

\section{Methods}

\section{Patient sample and data collection}

This is a retrospective, descriptive study with a crosssectional design, including 47 samples (36 CSF with 11 paired serum) obtained in the course of routine diagnostic testing during July 2014-July 2016. The samples were from 36 adult patients with suspected viral infection of the CNS or postinfectious syndromes living in the state of Rio de Janeiro,
Brazil. ${ }^{10,11}$ The patients were $23-75$ years old with a predominance of women $(66 \%)$. The neurologic manifestations included meningitis (9), encephalitis (9), encephalopathy (4), myelopathy (3), neuropathy (5), GBS (3), neuromyelitis optica spectrum disorder (1), and acute disseminated encephalomyelitis (1).

\section{Screening arbovirus investigation}

The presence of specific antibodies for DENV and CHIKV was determined in CSF and serum samples using commercial kits: Panbio Dengue IgM Capture ELISA, Panbio Dengue IgG Indirect ELISA (Standard Diagnostics, Republic of Korea), Anti-Chikungunya Virus ELISA (IgG), and AntiChikungunya Virus ELISA (IgM) (EUROIMMUN, Germany). For ZIKV, the immunochromatographic test ZIKV IgG/IgM RDT kit (GenBody Inc, Korea) was used. The amplification of the viral nucleic acid DENV, ZIKV, and CHIKV was performed by RT-PCR, as described in the literature. ${ }^{7,8}$

\section{CSF and serum analysis}

All CSF samples underwent routine diagnostic analysis, which included specific and global cell count and protein and glucose dosage and examinations for bacteria, fungi, mycobacteria, and syphilis. CSF and paired serum samples were evaluated for total IgG/albumin concentrations by nephelometry. Intrathecal synthesis of total IgG was calculated based on the intrathecal IgG fraction (IgG IF), which represents the percentage of total IgG concentration produced in the CSF. ${ }^{9}$ Blood-CSF barrier function was calculated by albumin quotient (CSF/serum). All cases had blood tests negative for antibodies against hepatitis $\mathrm{B}$ and $\mathrm{C}$, T-cell lymphotropic virus type 1 (HTLV-1), HIV, Cytomegalovirus, Epstein-Barr virus, and herpes simplex virus (HSV). CSF examinations were negative for bacteria, fungi, mycobacteria, and syphilis.

\section{Specific antibody index}

Intrathecal synthesis of specific IgG was quantitatively calculated using the specific IgG antibody index (AI IgG) and using commercial kits such as Panbio Dengue IgG Indirect ELISA (Standard Diagnostics, Republic of Korea) and AntiChikungunya Virus ELISA (IgG) (EUROIMMUN, Germany). It is based on the level of specific antibodies in serum, $\mathrm{CSF}$, and blood-CSF barrier function. ${ }^{9}$ Specific AI IgG $\geq 1.5$ is a criterion of intrathecal synthesis of specific antibodies. ${ }^{9}$

\section{Diagnosis criteria}

Laboratorial diagnosis of arbovirus was based on the detection of viral nucleic acid by RT-PCR in serum or CSF or specific IgM by ELISA assay in CSF. The presence of intrathecal synthesis of specific antibodies (specific AI) was considered as an additional support to the laboratorial diagnosis. Pleocytosis $\left(>4\right.$ cells $\left./ \mathrm{mm}^{3}\right)$, hyperproteinorrhachia ( $>40 \mathrm{mg} / \mathrm{dL}$ ), blood-CSF barrier dysfunction (albumin quotient $\mathrm{CSF} /$ serum $>8 \times 10^{-3}$ ), intrathecal synthesis of total $\operatorname{IgG}(\operatorname{IgG} I F>0)$, or intrathecal synthesis of specific IgG 
(specific AI IgG $\geq 1.5$ ) were indicative of the inflammatory reaction in CSF. ${ }^{9}$

\section{Standard protocol approvals, registrations, and patient consents}

This study was approved by the Ethical Review Board of HUGG/UNIRIO (54448216.2.0000.5258) and HUCFF/ UFRJ (58626816.9.000.5257).

\section{Data availability}

All data used in this study are anonymized and will be shared by request from any qualified investigator.

\section{Results}

\section{Clinical findings}

Table 1 shows the clinical characteristics of the 11 patients with a confirmed diagnosis (RT-PCR/IgM in CSF) of neuroinvasive arbovirus and 2 others who present only intrathecal synthesis of specific antibodies. In total, DENV was associated with neurological alteration in seven cases, and CHIKV in six cases. There was no case of ZIKV. Encephalitis was the most common neurologic manifestation ( 7 cases). Four of them were associated with DENV and 3 of them with CHIKV infection.

\section{Higher frequency of PCR detection}

The virologic study presented amplification for viral RNA in $19 \%$ (9/47) of serum and/or CSF, with 5 samples of DENV and 4 samples of CHIKV. The immunologic tests for specific IgM were reactive in 13\% (6/47) of samples: 1 for DENV and 5 for CHIKV. No samples were reactive for anti-ZIKV IgM (table 2). Specific reactive IgM in CSF and/or the presence of viral RNA in serum and/or CSF were detected in 15 of 47 $(32 \%)$ of the samples and in $31 \%(11 / 36)$ of the cases.

\section{Specific Al}

Three of 7 studied cases had intrathecal synthesis of specific $\operatorname{IgG}$ (table 2). Two of them were negative for arboviruses by RT-PCR or specific IgM: 1 case of DENV encephalitis (DENV AI IgG = 3.3) and 1 case of DENV associated with optic neuritis (DENV AI IgG = 4.9). CHIKV encephalitis was diagnosed using a specific AI (CHIKV AI IgG = 7.2) in a patient with reactive IgM CHIKV in serum and CSF diagnosed as encephalitis. ${ }^{6}$

\section{CSF analysis}

There were no red blood cells in CSF of the studied cases. Inflammatory CSF occurred in 54\% (7/13) of the positive arbovirus cases (pleocytosis and hyperproteinorrhachia): 3 had DENV infection (2 with encephalitis and 1 with neuromyelitis optica spectrum disorder) and 4 cases of CHIKV infection (encephalitis, myelitis, GBS, and neuropathy) (table 2). In addition, 3 cases (encephalitis, GBS, and polineuropathy) associated with CHIKV had protein-cytological dissociation. Hypoglycorrhachia was found in another patient with DENV-2 encephalitis. None of the cases had intrathecal synthesis of total IgG.
The intrathecal synthesis of specific IgG antibodies may represent an inflammatory biomarker for neurologic involvement associated with DENV and CHIKV.

\section{Discussion}

In this study, markers of arbovirus infection (DENV and CHIKV) were detected in 11 (31\%) cases with neurologic manifestations associated with infectious or postinfectious syndromes by RT-PCR in CSF/serum or IgM in CSF. Most of these $(81 \%)$ were confirmed by viral detection. In addition, 2 others cases (encephalitis and optic neuritis) had only intrathecal synthesis of DENV antibodies. The patients were seen in the city of Rio de Janeiro during arbovirus epidemic from July 2014 to July 2016, a period of low prevalence of ZIKV in adults. The laboratorial diagnosis was based on immunology and molecular biology techniques in CSF and/or serum. The detection of DENV IgM in CSF has a high specificity (97\%) for the neurologic diagnosis. ${ }^{5}$ In accordance with the criteria for defining neuroinvasive arbovirus cases by the Brazilian Ministry of Health and by the Centers for Disease Control and Prevention, we consider as confirmed cases of neuroinvasive arbovirus those that meet the following criteria: viral detection by RT-PCR in serum or CSF and/or detection of IgM antibodies in CSF by enzyme immunoassay (ELISA) with exclusion of endemic arbovirus. ${ }^{10,11}$ According to the Brazilian Health Ministry, the neuroinvasive arboviruses of major epidemiologic interest and public health importance in our country are genera Flavivirus, Alphavirus, and Orthobunyavirus, especially DENV, $\mathrm{CHIKV}$, and ZIKV. ${ }^{10}$ All our studied cases were screened for the 3 arboviruses not only by immunologic but also by molecular analysis. The patients also had clinical symptoms compatible with CHIKV infection (data not shown). We had no coinfections. Based on these data, we confirmed that $31 \%$ of our patients had neuroinvasive arbovirus (DENV or CHIKV).

In addition, we performed the detection of intrathecal synthesis of specific IgG using the specific AI. ${ }^{5,6,9}$ The specific IgG AI discriminates fractions of immunoglobulins produced in blood from those synthesized in the CNS against an agent. ${ }^{9}$ It may be useful in the differential diagnosis of neurologic disorders associated with arboviruses. The analysis of specific intrathecal synthesis of antibodies has been used to support the retrospective diagnosis of HSV, varicella zoster virus, measles, rubella, neuroborreliosis, and human $\mathrm{T}$-cell leukemia virus type 1 nervous system infection. ${ }^{5,6,9}$

Among the neurologic diseases associated with arboviruses, similar to previous reports, encephalitis was the most 
Table 1 Demographic data and clinical manifestations in 13 positive cases of DENV and/or CHIKV infection: 11 confirmed cases and 2 possible cases ( 15 and 30 )

\begin{tabular}{lllll}
\hline Case & Age/sex & City & Diagnosis/virus & Signs and symptoms \\
\hline $\mathbf{1 1}$ & 63/M & Rio de Janeiro & Encephalitis/DENV & $\begin{array}{l}\text { Fever, adynamia, hiporexia, weakness, } \\
\text { tetraparesis, paresthesia in upper limbs, } \\
\text { ptosis eyelid, diplopia and mydriasis on the } \\
\text { left, and holocranial headache }\end{array}$ \\
\hline $\mathbf{1 2}$ & 28/F & Fortaleza & Encephalitis/DENV & $\begin{array}{l}\text { Cognitive decline, tonic-clonic seizure, } \\
\text { dysarthria, and spastic tetraparesis }\end{array}$ \\
\hline $\mathbf{1 4}$ & 64/F & Rio de Janeiro & Encephalitis/CHIKV & $\begin{array}{l}\text { Fever, myalgia, arthralgia, asthenia, lethargy, } \\
\text { hypokalemia, hyponatremia, } \\
\text { hypophosphatemia, and tonic-clonic seizure; }\end{array}$ \\
\hline $\mathbf{1 5}$ & 45/F & Unknown & Encephalitis/DENV & $\begin{array}{l}\text { Behavior change (disinhibition), abnormal } \\
\text { gait, disorientation, and memory loss. }\end{array}$ \\
\hline $\mathbf{1 6}$ & 63/F & Rio de Janeiro & Encephalitis/CHIKV & $\begin{array}{l}\text { Fever, arthralgia, edema in the lower limbs, } \\
\text { prostration, cognitive alterations, skin rash, } \\
\text { pruritus. }\end{array}$
\end{tabular}

\begin{tabular}{|c|c|c|c|c|c|}
\hline 17 & $75 / \mathrm{M}$ & Campina Grande & Encephalitis/CHIKV & $\begin{array}{l}\text { Fever, prostration, myalgia, diffuse } \\
\text { maculopapular rash, oliguria, disorientation, } \\
\text { lethargy, and reduced GCS }\end{array}$ & Hospital release \\
\hline 18 & $27 / F$ & Rio de Janeiro & Encephalitis/DENV & $\begin{array}{l}\text { Diplopia, nausea, vomiting, asthenia, } \\
\text { headache, ataxic march, Romberg sign, } \\
\text { multidirectional nystagmus, and head- } \\
\text { shaking maneuver positive. }\end{array}$ & Hospital release \\
\hline 26 & $59 / F$ & Rio de Janeiro & GBS/CHIKV & $\begin{array}{l}\text { Constipation, ascending paraparesis, } \\
\text { dysphonia, facial diparesis, cervical } \\
\text { paresthesia, global areflexia, bilateral tactile } \\
\text { and painful bilateral hypesthesia in the lower } \\
\text { limbs and hands, and tetraplegia. }\end{array}$ & Hospital release \\
\hline 28 & $48 / F$ & Rio de Janeiro & GBS/DENV & $\begin{array}{l}\text { Severe chest pain, dry cough, herpes zoster, } \\
\text { arthralgia, pneumonia, breathlessness, and } \\
\text { cardiopulmonary arrest }\end{array}$ & Death \\
\hline 30 & $22 / \mathrm{M}$ & Unknown & Optic neuritis/DENV & Subacute loss of both visual fields & Unknown \\
\hline 33 & $52 / F$ & Rio de Janeiro & Polyneuropathy/CHIKV & $\begin{array}{l}\text { Paresthesia in the lower limbs and hands, } \\
\text { paraplegia, deep bilateral upper limb flexure, } \\
\text { hypotonia and bilateral areflexia in the upper } \\
\text { limbs, hyperalgesia to mild plantar } \\
\text { stimulation, and superficial and deep } \\
\text { hypesthesia. }\end{array}$ & Hospital release \\
\hline
\end{tabular}

\begin{tabular}{lll}
\hline 34 64/M & Myelitis/CHIKV de Janeiro & $\begin{array}{l}\text { Romberg sign, urinay retention, paraplegia, } \\
\text { spasticity in the lower limbs, reduced } \\
\text { segmental proprioception, tactile and painful } \\
\text { hypesthesia at the T2 level, and hiporreflexia } \\
\text { in the upper limbs. }\end{array}$ \\
\end{tabular}

Abbreviations: CHIKV = Chikungunya virus; DENV = Dengue virus; F= Female; GBS: Guillain-Barré syndrome; M = Male; NMOSD = neuromyelitis optica spectrum disorder.

frequent manifestation. It included 7 cases (54\%): 4 by DENV (DENV-2, DENV-3) and 3 by CHIKV. We detected two cases of GBS (18\%): 1 by DENV and 1 by CHIKV infection. In addition, it was found that one case of myelitis and one of polyneuropathy caused by CHIKV as well as a case of autoimmune disorder and optic neuritis were associated with DENV. Amplification occurred in paired serum and CSF of 2 patients. One of them by DENV-3 and another by CHIKV.

In DENV, it is estimated that $0.5 \%-21 \%$ of patients develop neurologic manifestations. ${ }^{2}$ DENV-2 and DENV-3 are the most commonly found in cases of myelitis, meningitis, and encephalitis. ${ }^{2}$ Regarding CHIKV, since the 1960s, it has been known that the infection affects the CNS. ${ }^{3}$ During the 2006 epidemic in India, $16.3 \%$ of cases of neurologic manifestations were caused by CHIKV. In 2016, the cohort study conducted at La Réunion Island was associated with CHIKV infection in $42 \%$ of cases of encephalitis. ${ }^{4}$

The detection of viral RNA and specific IgM in CSF are indicative of the viral infection in the CNS. The intrathecal synthesis of specific IgG antibodies may represent an inflammatory biomarker for neurologic involvement associated with DENV and CHIKV. In addition, the combined use of CSF and serum 
Table 2 CSF findings of 13 cases with neurologic disorders associated with DENV or CHIKV infection: 11 confirmed cases and 2 possible cases (15 and 30 )

\begin{tabular}{|c|c|c|c|c|c|}
\hline \multirow[b]{2}{*}{ Case } & \multirow[b]{2}{*}{ Neurologic manifestation } & \multicolumn{3}{|l|}{ CSF analysis $^{a}$} & \multirow[b]{2}{*}{ Positivity criteria } \\
\hline & & Cell count $/ \mathrm{mm}^{3}$ & Protein $(\mathrm{mg} / \mathrm{dL})$ & Glucose (mg/dL) & \\
\hline 11 & Encephalitis & 1 & 32 & 79 & Amplification for DENV-3 in CSF \\
\hline 12 & Encephalitis & 7 & 77 & 58 & Reactive IgM for DENV in CSF \\
\hline 14 & Encephalitis & 1 & 77 & 98 & $\begin{array}{l}\text { Amplification for CHIKV in CSF and serum. } \\
\text { Reactive IgM for CHIKV in CSF }\end{array}$ \\
\hline 15 & Encephalitis & 1 & 35 & 64 & Al IgG for $D E N V \geq 1.5$ \\
\hline 16 & Encephalitis & 1 & 29 & 40 & $\begin{array}{l}\text { Reactive IgM for CHIKV in serum and CSF. AI } \\
\text { IgG for } \mathrm{CHIKV} \geq 1.5\end{array}$ \\
\hline 17 & Encephalitis & 70 & 67 & 71 & Reactive IgM for CHIKV in CSF \\
\hline 18 & Encephalitis & 24 & 81 & 34 & Amplification for DENV-2 in CSF \\
\hline 26 & GBS & 9 & 216 & 82 & Amplification for CHIKV in CSF \\
\hline 28 & GBS & 1 & 28 & 56 & Amplification for DENV-3 in CSF and serum \\
\hline 30 & Neuritis & 1 & 23 & 63 & Al IgG for $D E N V \geq 1.5$ \\
\hline 33 & Polyneuropathy & 8 & 240 & 63 & Amplification for CHIKV in CSF \\
\hline 34 & Myelitis & 32 & 59 & 43 & Reactive IgM for CHIKV in CSF \\
\hline 35 & NMOSD & 120 & 35 & 78 & Amplification for DENV-1 in serum \\
\hline
\end{tabular}

Abbreviations: $\mathrm{CHIKV}=$ Chikungunya virus; DENV = Dengue virus; GBS = Guillain-Barré syndrome; NMOSD = neuromyelitis optica spectrum disorder. There were no red blood cells in CSF.

a Reference values: Pleocytosis $>4$ cells $/ \mathrm{mm}^{3}$; hypoglycorrhachia $<40 \mathrm{mg} / \mathrm{dL}$; hyperproteinorrhachia $>40 \mathrm{mg} / \mathrm{dL}$; specific Al lgG $\geq 1.5=$ intrathecal synthesis of specific antibodies.

for the calculation of the AI IgG increases the diagnostic accuracy of neurologic diseases caused by DENV and CHIKV, which can support the retrospective diagnosis, especially during epidemics, avoiding possible sequels and improving the quality of life of patients. Cases of encephalitis, myelitis, aseptic meningitis, and postinfectious neurologic syndromes should be screened for neuroinvasive arbovirus in endemic areas.

\section{Study funding}

This work is part of a research network of arbovirus studies in Rio de Janeiro, Brazil. It was supported by "Fundação de Amparo à Pesquisa do Estado do Rio de Janeiro (FAPERJ)," "Edital Programa Pesquisa em Zika, Chikungunya e Dengue-no 18/2015," "Conselho Nacional de Desenvolvimento Científico e Tecnológico (CNPq)," and "Edital Apoio Rede Zika Multicêntrico (439928/2016-8),” Brazil. The authors also thank for the $\mathrm{PhD}$ fellowship from Coordenação de Aperfeiçoamento de Pessoal de Nível Superior (CAPES) in the Post-Graduation on Infectious and Parasitic Diseases (UFRJ) to C.M. and a post-PhD fellowship from FAPERJ to M.J.C.C.

\section{Disclosure}

The authors report no disclosures relevant to this manuscript. Full disclosure form information provided by the authors is available with the full text of this article at Neurology.org/cp.

\section{Publication history}

Received by Neurology: Clinical Practice May 31, 2019. Accepted in final form October 21, 2019.

Appendix Authors

\begin{tabular}{|c|c|c|c|}
\hline Name & Location & Role & Contribution \\
\hline $\begin{array}{l}\text { Cíntia da Silva } \\
\text { Mello, MSc }\end{array}$ & $\begin{array}{l}\text { Universidade Federal } \\
\text { do Rio de Janeiro } \\
\text { (UFRJ); and } \\
\text { Universidade Federal } \\
\text { do Estado do Rio de } \\
\text { Janeiro (UNIRIO), Rio } \\
\text { de Janeiro, Brazil }\end{array}$ & Author & $\begin{array}{l}\text { Concept, acquisition } \\
\text { and interpretation of } \\
\text { data, and performed } \\
\text { the laboratorial } \\
\text { analysis and critical } \\
\text { revision }\end{array}$ \\
\hline $\begin{array}{l}\text { Mauro Jorge } \\
\text { Cabral-Castro, } \\
\text { PhD }\end{array}$ & $\begin{array}{l}\text { Universidade Federal } \\
\text { do Rio de Janeiro } \\
\text { (UFRJ), Rio de Janeiro, } \\
\text { Brazil }\end{array}$ & Author & $\begin{array}{l}\text { Concept, acquisition } \\
\text { interpretation of the } \\
\text { data, and performed } \\
\text { the laboratorial } \\
\text { analysis and critical } \\
\text { revision }\end{array}$ \\
\hline $\begin{array}{l}\text { Luiz Claudio } \\
\text { Silva de Faria, } \\
\text { BSc }\end{array}$ & $\begin{array}{l}\text { Universidade Federal } \\
\text { do Rio de Janeiro } \\
\text { (UFRJ), Rio de Janeiro, } \\
\text { Brazil }\end{array}$ & Author & $\begin{array}{l}\text { Concept, acquisition } \\
\text { interpretation of the } \\
\text { data, and performed } \\
\text { the laboratorial } \\
\text { analysis and critical } \\
\text { revision }\end{array}$ \\
\hline $\begin{array}{l}\text { José Mauro } \\
\text { Peralta, MD, } \\
\text { PhD }\end{array}$ & $\begin{array}{l}\text { Universidade Federal } \\
\text { do Rio de Janeiro } \\
\text { (UFRJ), Rio de Janeiro, } \\
\text { Brazil }\end{array}$ & Author & $\begin{array}{l}\text { Concept, acquisition } \\
\text { interpretation of the } \\
\text { data, and critical } \\
\text { revision }\end{array}$ \\
\hline
\end{tabular}

Continued 


\section{Appendix (continued)}

\begin{tabular}{|c|c|c|c|}
\hline Name & Location & Role & Contribution \\
\hline $\begin{array}{l}\text { Marzia Puccioni- } \\
\text { Sohler, MD, PhD. }\end{array}$ & $\begin{array}{l}\text { Universidade Federal } \\
\text { do Rio de Janeiro } \\
\text { (UFRJ); Universidade } \\
\text { Federal do Estado do } \\
\text { Rio de Janeiro } \\
\text { (UNIRIO), Rio de } \\
\text { Janeiro, Brazil }\end{array}$ & Author & $\begin{array}{l}\text { Concept, acquisition } \\
\text { interpretation of the } \\
\text { data, drafted the } \\
\text { manuscript, and } \\
\text { critical revision }\end{array}$ \\
\hline
\end{tabular}

\section{References}

1. World Health Organization (WHO) and the Special Programme for Research and Tropical Diseases (TDR). Dengue guidelines for diagnosis, treatment, prevention, and control. Prev Control 2009:147.

2. Carod-Artal FJ, Wichmann O, Farrar J, Gascón J. Neurological complications of Dengue virus infection. Lancet Neurol 2013;12:906-919.

3. Carey DE, Myers RM, Deranitz CM, Jadhav M, Reuben R. The 1964 Chikungunya epidemic at Vellore, South India, including observations on concurrent Dengue. Trans R Soc Trop Med Hyg 1969;63:434-445.
4. Gérardin P, Couderc T, Bintner M, et al. Chikungunya virus-associated encephalitis: a cohort study on La Réunion Island, 2005-2009. Neurology 2016;86. 94-102.

5. Puccioni-Sohler M, Soares CN, Papaiz-Alvarenga R, et al. Neurologic Dengue manifestations associated with intrathecal specific immune response. Neurology 2009;73: 1413-1417.

6. Puccioni-Sohler M, Farias LC, Cabral-Castro MJ, et al. Cerebrospinal fluid immunoglobulins as potential biomarkers of Chikungunya encephalitis. Emerg Infect Dis 2018;24:939-941.

7. Lanciotti RS, Calisher CH, Gubler DJ, Chang GJ, Vorndam AV. Rapid detection and typing of dengue viruses from clinical samples by using reverse transcriptase-polymerase chain reaction. J Clin Microbiol 1992;30: 545-551.

8. Lanciotti RS, Kosoy OL, Laven JJ, et al. Chikungunya virus in US travelers returning from India, 2006. Emerg Infect Dis 2007;13:764-767.

9. Reiber H, Felgenhauer K. Protein transfer at the blood cerebrospinal fluid barrier and the quantitation of the humoral immune response within the central nervous system. Clin Chim Acta 1987;163:319-28.

10. Ministério da Saúde. Manual de vigilância sentinela de doenças neuroinvasivas por arbovírus (Sentinel Surveillance Manual for Neuroinvasive Arboviral Diseases). 1st ed. Brazil: Ministério da Saúde; 2017:44.

11. CDC Guidelines. 2015. Available at: wwwn.cdc.gov/nndss/conditions/arboviraldiseases-neuroinvasive-and-non-neuroinvasive/case-definition/2015/. Accessed August 7, 2019 


\section{Neurology ${ }^{\circ}$ Clinical Practice}

\section{Dengue and chikungunya infection in neurologic disorders from endemic areas in Brazil}

Cíntia da Silva Mello, Mauro Jorge Cabral-Castro, Luiz Claudio Silva de Faria, et al. Neurol Clin Pract published online November 25, 2019

DOI 10.1212/CPJ.0000000000000776

This information is current as of November 25, 2019

\begin{abstract}
Updated Information \& Services

Subspecialty Collections

Permissions \& Licensing

Reprints

including high resolution figures, can be found at: http://cp.neurology.org/content/early/2019/11/24/CPJ.00000000000007 76.full.html

This article, along with others on similar topics, appears in the following collection(s):

Cerebrospinal Fluid

http://cp.neurology.org//cgi/collection/cerebrospinal_fluid

Encephalitis

http://cp.neurology.org//cgi/collection/encephalitis

Viral infections

http://cp.neurology.org//cgi/collection/viral_infections its entirety can be found online at:

http://cp.neurology.org/misc/about.xhtml\#permissions

Information about ordering reprints can be found online: http://cp.neurology.org/misc/addir.xhtml\#reprintsus
\end{abstract}

Information about reproducing this article in parts (figures,tables) or in

Neurol Clin Pract is an official journal of the American Academy of Neurology. Published continuously since 2011, it is now a bimonthly with 6 issues per year. Copyright ( 2019 American Academy of Neurology. All rights reserved. Print ISSN: 2163-0402. Online ISSN: 2163-0933.

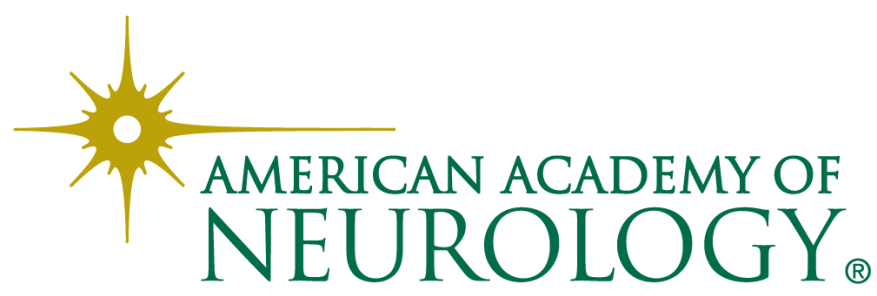

